Article

\title{
Evaluation of a Low-Moisture, Molasses-Based Block Containing Organic Sources of Trace Minerals and a Saccharomyces cerevisiae Fermentation Culture during the Feedlot Receiving Phase on Growth Performance, Efficiency of Dietary Net Energy Utilization, and Liver Trace Mineral Status in Newly Weaned Steer Calves
}

\author{
Thomas G. Hamilton, Warren C. Rusche ${ }^{(1)}$, Cody L. Wright, Julie A. Walker and Zachary K. Smith * \\ Department of Animal Science, South Dakota State University, Brookings, SD 57007, USA; \\ Thomas.Hamilton@sdstate.edu (T.G.H.); Warren.Rusche@sdstate.edu (W.C.R.); \\ Cody.wright@sdstate.edu (C.L.W.); Julie.walker@sdstate.edu (J.A.W.) \\ * Correspondence: zachary.smith@sdstate.edu
}

check for

updates

Citation: Hamilton, T.G.; Rusche, W.C.; Wright, C.L.; Walker, J.A.; Smith, Z.K. Evaluation of a Low-Moisture, Molasses-Based Block Containing Organic Sources of Trace Minerals and a Saccharomyces cerevisiae Fermentation Culture during the Feedlot Receiving Phase on Growth Performance, Efficiency of Dietary Net Energy Utilization, and Liver Trace Mineral Status in Newly Weaned Steer Calves. Ruminants 2021, 1, 137-146. https://doi.org/10.3390/ ruminants1020011

Academic Editors: Ulrich Meyer

Received: 1 September 2021

Accepted: 25 October 2021

Published: 1 November 2021

Publisher's Note: MDPI stays neutral with regard to jurisdictional claims in published maps and institutional affiliations.

Copyright: (C) 2021 by the authors. Licensee MDPI, Basel, Switzerland. This article is an open access article distributed under the terms and conditions of the Creative Commons Attribution (CC BY) license (https:// creativecommons.org/licenses/by/ $4.0 /)$.

\begin{abstract}
The objective of this study was to evaluate the growth performance responses and liver trace mineral status of newly weaned steer calves offered a low-moisture, molasses-based block "stress tub" containing organic sources of trace minerals and a Saccharomyces cerevisiae fermentation culture during the first 21- $d$ of a 42-d feedlot receiving phase. Newly weaned, single source Charolais $\times$ Angus steer calves $(n=46$; body weight $[\mathrm{BW}]=240 ; \mathrm{SEM}=1.0 \mathrm{~kg}$ ) were used in a 42-d randomized complete block design feedlot receiving experiment. On $\mathrm{d}-1$ all steers were individually weighed in the morning for allotment purposes, and steers were then stratified by initial BW and allotted to one of ten pens ( $n=4$ to 5 steers per pen; 5 pens per treatment) that were randomly assigned to 1 of 2 treatments: (1) no cooked molasses "stress" tub (Con) or (2) ad libitum access to a cooked molasses "stress" tub (Stress Tub; Purina Animal Nutrition, St. Louis, MO, USA) for the first 21-d (Tub). Steers were allotted to their study pens within $36 \mathrm{~h}$ of weaning, and the "stress" tub was introduced approximately $24 \mathrm{~h}$ post arrival. During the initial 14-d on feed, intake was managed by feed calls to accommodate adaptation to the receiving diet. Following the adaptation period, bunks were managed using a slick bunk management approach. Tub disappearance was monitored daily. Liver biopsies ( $n=2$ steers/pen) were collected on d 7, 21, and 42 for the determination of $\mathrm{Co}, \mathrm{Cu}, \mathrm{Mn}$, and $\mathrm{Zn}$. From $\mathrm{d} 0$ to 21 and d 0 to 42 , steers from the Tub treatment consumed greater $(p \leq 0.01)$ amounts of $\mathrm{Co}, \mathrm{Cu}, \mathrm{Mn}$, and $\mathrm{Zn}$ compared with those in the Con treatment. A treatment $\times$ day interaction for hepatic concentrations of $\mathrm{Co}(p=0.09), \mathrm{Cu}(p=0.01)$, and $\mathrm{Zn}(p=0.01)$ were noted. On d 7, steers from Tub had greater $(p \leq 0.01)$ hepatic $\mathrm{Co}, \mathrm{Cu}$, and $\mathrm{Zn}$ concentrations compared with Con. On d 21, steers from Tub had greater $(p \leq 0.01)$ hepatic concentrations of $\mathrm{Co}$ and $\mathrm{Cu}$; hepatic $\mathrm{Zn}$ was similar between treatments $(p=0.83)$. On study d 42 steers from Tub had greater $(p=0.01)$ hepatic $\mathrm{Cu}$; however, hepatic concentrations for Co or $\mathrm{Zn}$ did not differ $(p \geq 0.34)$. During the initial $21 \mathrm{~d}$ of the experiment, gain efficiency was enhanced ( $p=0.03$ ) by $25.0 \%$ in steers from Tub compared with Con. Cumulative ADG, DMI, dietary NE utilization and G:F did not differ $(p \geq 0.14)$ between treatments. It is concluded that the use of stress tubs does not influence the overall growth performance or NE value of the diet during a $42-d$ receiving period. Stress tub consumption increased hepatic mineral stores during the initial 21-d period and enhanced the $\mathrm{Cu}$ status of calves throughout the 42-d period.
\end{abstract}

Keywords: receiving; cattle; molasses; trace minerals

\section{Introduction}

The period when calves are newly weaned and transported to the feedlot is a critical time in the beef production system. This period is arguably the most stressful event of a 
beef calf's life as they are weaned, transported, deprived of feed and water, and introduced to an unfamiliar feed source [1]. The physical and psychological stress of weaning may have both short- and long-term impacts on calf health and performance [2]. Stress at weaning can be attributed to two significant transitional factors: social transition and environmental transition. A social transition must take place as calves are separated from their mothers who have provided social direction and guidance since birth. A new social structure and hierarchy must be established now that the calves are solely amongst their peers. Transitioning to a new environment also inflicts a great deal of stress on calves as they must adapt to drinking from a foreign water source and learn to eat from feed bunk. Being enclosed in a small pen with either a dirt or cement surface will also prove foreign to the naïve calf. Using products and management techniques to help mitigate this stress through weaning, and the pre-conditioning period can result in improved production levels. Placing feeders and the water source along the perimeter of the pen can lead to increased exposure to both the water and feed source and work to minimize perimeter walking. Avoiding things such as castration, dehorning, and branding within the weeks prior to or post-weaning can help reduce unnecessary stress. Products such as vaccinations and mineral supplements prior to and during weaning can promote antibody production and a heightened immune response to fight of illness during this stressful period. Trace minerals such as $\mathrm{Zn}, \mathrm{Cu}, \mathrm{Cr}$, and Se are supplemented occasionally in receiving cattle diets because of their possible impacts on immune function [3]. Cooked, low-moisture, molasses-based "stress" tubs have become a popular tool for free choice supplementation of trace minerals in newly weaned calves in the southern U.S. under pasture-based conditions [4] and in yearling cattle under dry-lot conditions [5]. Additionally, use of live Saccharomyces cerevisiae products in receiving calves has been shown to enhance growth performance [6-8]. Saccharomyces cerevisiae is a yeast that is easily cultured and often utilized in the baking industry. In cattle it is used to modify rumen fermentation and the bacterial population that resides in the rumen [9]. To our knowledge, no research has been conducted regarding the voluntary molasses-based block intake, animal growth performance responses, and hepatic mineral status of newly weaned calves offered a molasses-based "stress" tub upon introduction to the feedlot. The objective of this experiment was to determine the influence that cooked molasses "stress" tubs containing organic sources of trace minerals and a Saccharomyces cerevisiae fermentation culture have on animal growth performance, measures of applied energetics, and hepatic trace mineral status in newly weaned beef steer calves.

\section{Materials and Methods}

\subsection{Institutional Animal Care and Use Approval}

This study was conducted at the Ruminant Nutrition Center (RNC) in Brookings, SD, USA between October and November of 2020. The animal care and handling procedures used in this study were approved by the South Dakota State University Animal Care and Use Committee (Approval Number: 2002-004E).

\subsection{Treatments}

This study used 5 replicate pens of 4 to 5 steers assigned to one of two receiving cattle management treatments: (1) no cooked molasses "stress" tub (Con) and (2) ad libitum access to a cooked molasses "stress" tub (Table 1; Stress Tub; Purina Animal Nutrition, St. Louis, MO, USA) for the first $21 \mathrm{~d}$ of a 42 -d receiving period, according to manufacturer's recommendations (Tub). 
Table 1. Minimum guaranteed analysis (as-is basis) for the low-moisture, molasses-based block (Stress Tub; Purina Animal Nutrition, St. Louis, MO, USA) ${ }^{1}$.

\begin{tabular}{cr}
\hline Item & Value \\
\hline Crude protein, \% & 12.00 \\
Crude fat, \% & 4.00 \\
Crude fiber, \% & 4.00 \\
Calcium, \% & 2.00 \\
Phosphorus, \% & 1.00 \\
Salt, \% & 1.50 \\
Magnesium, \% & 1.00 \\
Potassium, \% & 2.00 \\
Manganese, ppm & 1300.00 \\
Cobalt, ppm & 60.00 \\
Copper, ppm & 785.00 \\
Iodine, ppm & 40.00 \\
Selenium, ppm & 13.00 \\
Zinc, ppm & 2500.00 \\
Vitamin A, IU / kg & $440,920.00$ \\
Vitamin D, IU $/ \mathrm{kg}$ & $49,603.50$ \\
Vitamin E, IU/kg & 1763.68 \\
\hline
\end{tabular}

${ }^{1}$ Each $0.227 \mathrm{~kg}$ (as-is) an organic trace mineral product that provided: $200.2 \mathrm{mg}$ of manganese, $12.6 \mathrm{mg}$ of cobalt $126.0 \mathrm{mg}$ of copper, and $360.5 \mathrm{mg}$ of zinc in each in each $0.227 \mathrm{~kg}$ (Availa 4; Zinpro, Eden Prairie, MN) and $14 \mathrm{~g}$ of Saccharomyces cerevisiae fermentation product (Diamond V Original XPC; Cedar Rapids, IA).

\subsection{Animals, Initial Processing, and Study Initiation}

This study used 46 single source, newly weaned Charolais $\times$ Angus steer calves (initial $\mathrm{BW}=240 ; \mathrm{SEM}=1.0 \mathrm{~kg}$ ). Steers were transported $512 \mathrm{~km}$ (approximately 6-h transit) from a ranch in western South Dakota to the RNC on October 19, 2020. Upon arrival, all steers were group housed and provided unlimited access to long-stem grass hay and water. The following morning, all steers were individually weighed, assigned a unique identification tag, vaccinated for viral respiratory pathogens (Bovishield Gold 5; Zoetis, Parsippany, NJ, USA) and clostridial species (Ultrabac 7/Somubac; Zoetis, Parsippany, NJ, USA), and administered a pour-on moxidectin (Cydectin; Bayer Animal Health, Shawnee Mission, KS, USA) according to label instructions. Steers were not implanted during the initial processing procedure as steers had been administered a non-steroidal anabolic implant at the ranch approximately $45-\mathrm{d}$ prior to the initiation of the present experiment (36 mg zeranol; Ralgro; Merck Animal Health, DeSoto, KS). Steers were blocked by initial BW and allotted to their treatment pens ( $\mathrm{n}=5$ pens/treatment: 4 to 5 steers $/$ pen). Pens were $7.6 \times 7.6 \mathrm{~m}$ concrete surface pens with $7.6 \mathrm{~m}$ of linear bunk space and equipped with a heated, continuous flow concrete waterer. The "stress" tubs were introduced to the appropriate treatment pens approximately $24 \mathrm{~h}$ following arrival to the RNC where they were placed at the back of the pen opposite of the feed bunk to allow for cattle who are not actively attempting to consume feed from the manger an opportunity to consume the "stress" tub. Bedding was applied as needed to provide a dry, bedded area for all the steers within a pen to lay down.

\subsection{Diet and Intake Management}

All steers were fed twice daily ( $0900 \mathrm{~h}$ and $1500 \mathrm{~h}$ ) in equal proportions. Feed batching was carried out such that all pens within a treatment were fed out of the same batch of feed. During the initial 14- $\mathrm{d}$ on feed, intake was closely managed by feed calls to accommodate adaptation to the receiving diet. For the remainder of the experiment (d 15 to 42 ), bunks were managed using a slick bunk management approach such that bunks were managed to be devoid of feed by $0800 \mathrm{~h}$ most mornings. Weekly ingredient samples were dried in a forced air oven at $60^{\circ} \mathrm{C}$ until no further weight change occurred. Individual commodity ingredients collected each week were ground to 1-mm and composited by 21-d period for nutrient analyses at a commercial laboratory using AOAC procedures (Table 2, Servi-Tech, 
Hastings, NE, USA), and tabular energy values according to Preston [10] were used for determination of tabular dietary net energy (NE) content. Feed intake and ingredient inclusion (DM basis) were summarized at weekly intervals. Tub consumption was monitored daily for disappearance rate. At approximately $0700 \mathrm{~h}$ each morning, tubs were removed from each pen and weighed on a scale to the nearest $0.0454 \mathrm{~kg}$. Daily tub consumption was determined from daily disappearance rate divided by the number of heads in the pen.

Table 2. Actual diet formulation based upon weekly DM determinations of ingredients and nutrient composition based upon 21-d period composites of weekly ingredients and reconstructed diet composition (DM basis) for nutrient content determination ${ }^{1}$.

\begin{tabular}{|c|c|c|}
\hline Item & D 1 to 21 & D 22 to 42 \\
\hline Corn silage, $\%$ & 65.20 & 64.13 \\
\hline DDGS $^{2}, \%$ & 19.42 & 19.98 \\
\hline Oat hay, \% & 9.53 & 9.90 \\
\hline Pelleted supplement ${ }^{3}, \%$ & 5.85 & 5.99 \\
\hline Diet DM, \% & 43.49 & 42.49 \\
\hline $\mathrm{CP}^{4}, \%$ & 12.70 & 13.60 \\
\hline $\mathrm{NDF}^{5}, \%$ & 37.50 & 40.80 \\
\hline $\operatorname{ADF}^{6}, \%$ & 20.90 & 23.20 \\
\hline Ash, \% & 5.90 & 6.50 \\
\hline $\mathrm{Ca}, \%$ & 0.57 & 0.66 \\
\hline $\mathrm{P}, \%$ & 0.30 & 0.33 \\
\hline $\mathrm{Mg}, \%$ & 0.18 & 0.19 \\
\hline $\mathrm{K}, \%$ & 0.93 & 1.02 \\
\hline $\mathrm{S}, \%$ & 0.18 & 0.21 \\
\hline $\mathrm{Co}, \mathrm{mg} / \mathrm{kg}$ & 0.70 & 0.50 \\
\hline $\mathrm{Cu}, \mathrm{mg} / \mathrm{kg}$ & 40.00 & 53.00 \\
\hline Mo, mg/kg & 0.70 & 0.70 \\
\hline $\mathrm{Mn}, \mathrm{mg} / \mathrm{kg}$ & 59.00 & 66.00 \\
\hline $\mathrm{Zn}, \mathrm{mg} / \mathrm{kg}$ & 98.00 & 137.00 \\
\hline $\mathrm{NEm}^{7}, \mathrm{Mcal} / \mathrm{kg}$ & 1.74 & 1.74 \\
\hline $\mathrm{NEg}^{8}, \mathrm{Mcal} / \mathrm{kg}$ & 1.11 & 1.10 \\
\hline
\end{tabular}

${ }^{1}$ All values except for dry matter (DM) on a DM basis. ${ }^{2}$ Dried distillers grains plus solubles. ${ }^{3}$ Pelleted supplement contained (DM basis): $63 \%$ soybean meal, $12.3 \%$ soybean hulls, $5.0 \%$ trace mineralized salt, $18.5 \%$ calcium carbonate, and $1.2 \%$ of a vitamin premix that contained (in each $907-\mathrm{kg}$ of supplement): $7123 \mathrm{~g}$ of soybean meal, $404 \mathrm{~g}$ of monensin sodium (Rumensin 90; Elanco, Indianapolis, IN), $49 \mathrm{~g}$ of vitamin A (650,000 IU/g), $769 \mathrm{~g}$ of vitamin E (500 IU/g), $726 \mathrm{~g}$ of Zn hydroxychloride (IntelliBond Z; Micronutrients, Indianapolis, IN), and $201 \mathrm{~g}$ tri-basic copper chloride (IntelliBond C; Micronutrients, Indianapolis, IN). ${ }^{4}$ Crude protein. ${ }^{5}$ Neutral detergent fiber. ${ }^{6}$ Acid detergent fiber. ${ }^{7}$ Net energy for maintenance. ${ }^{8}$ Net energy for gain.

\subsection{Liver Biopsy and Hepatic Mineral Determination}

Liver biopsies were collected on d 7, 21, and 42 using the method described [11]. Briefly, steers were secured in a hydraulic squeeze chute with mild squeeze pressure. The biopsy was collected through an incision in the 11th intercostal space (between the 11th and 12th ribs) on a line from the hook bone (tubercoxae) to the point of the shoulder (scapulo-humoral joint). Hair was clipped from an area approximately $10.16 \mathrm{~cm} \times 10.16 \mathrm{~cm}$ around the biopsy site. The surgical site was prepared with iodine and 70\% isopropyl alcohol. A $6.35 \mathrm{~mm}$ incision was made by inserting a scalpel blade through the skin and intercostal muscle tissue, perpendicular to the body wall. Surgical tubing was applied to the biopsy needle (DJ-series Jamshidi bone marrow needle 8 ga and $10.16 \mathrm{~cm}$ long; Cardinal Health catalog number DJ4008X 13), which was inserted into the incision site then into the liver and was used to collect hepatic tissue by using back pressure on a $10 \mathrm{~mL}$ syringe. Contents were carefully emptied from the syringe and surgical tubing into a weigh boat, and excess blood was poured-off. The remaining sample was washed with $0.01 \mathrm{M}$ of phosphate buffered saline (PBS), and the PBS rinse was repeated as necessary to remove excess blood. Wounds were sprayed with iodine, and biopsy sites were checked for swelling and complications at $24 \mathrm{~h}$ and $48 \mathrm{~h}$ post-biopsy. No complications were noted due to the liver biopsy procedure in the present study. Steers selected for liver biopsies 
( $n=2$ steers/pen) were selected based on being the closest to the initial pen mean BW for each pen. Hepatic samples were shipped to Michigan State University Diagnostic Center for Population and Animal Health (Lansing, MI, USA) for analysis of hepatic mineral content. Concentrations of $\mathrm{Co}, \mathrm{Cu}, \mathrm{Mn}$, and $\mathrm{Zn}$ were measured using an Agilent 7500ce Inductively Coupled Plasma Mass Spectrometer (Agilent Technologies Inc., Santa Clara, CA, USA) via procedures reported by [12].

\subsection{Growth Performance Calculations}

Steers were weighed prior to feeding, initially and on $\mathrm{d} 7,21$, and 42 . Growth performance data were summarized from initial to d 21 (treatment phase), $\mathrm{d} 22$ to $\mathrm{d} 42$ (no treatment phase), and from initial to d 42 (cumulative). Initial BW was not shrunk, all other BW measures were pencil shrunk by $4 \%$ to account for digestive tract fill. Average daily gain (ADG) was determined using the difference between each beginning and ending period weight divided by days on feed. Efficiency of weight gain $(\mathrm{G}: \mathrm{F})$ was calculated by dividing the period ADG by the period daily DMI. Body weight at $28 \%$ empty body fatness for these steers was estimated to be $625 \mathrm{~kg}$ [13]. Observed dietary NE was calculated from daily energy gain (EG; Mcal/d): $E G=\left(A D G\right.$ from initial to d 42) ${ }^{1.097} \times 0.0557 \mathrm{~W}^{0.75}$, where $\mathrm{W}$ is the mean equivalent $\mathrm{BW}$ [average $\mathrm{BW} \times(478 / 625), \mathrm{kg}$; [14]. Maintenance energy required (EM; Mcal/d) was calculated by the following equation: $\mathrm{EM}=0.077 \mathrm{BW}^{0.75}$ [15], where BW is the mean trial BW $(\mathrm{kg})$. Using the estimates required for maintenance and gain, the observed dietary NEm and NEg values [16] of the diet were generated using the quadratic formula: $x=\frac{-b \pm \sqrt{b^{2}-4 a c}}{2 c}$, where $x=N E m, M c a l / k g, a=-0.41 E M$, $\mathrm{b}=0.877 \mathrm{EM}+0.41 \mathrm{DMI}+\mathrm{EG}, \mathrm{c}=-0.877 \mathrm{DMI}$, and NEg was determined from: 0.877NEm $-0.41[17,18]$. The ratio of observed-to-expected NE was determined from observed dietary NE for maintenance or gain/tabular NE for maintenance or gain.

\subsection{Statistical Analysis}

All data were analyzed as a randomized complete block design and pen served as the experimental unit. Growth performance data were analyzed using the GLIMMIX procedure of SAS 9.4 (SAS Inst., Inc., Cary, NC, USA). The model included the fixed effect of treatment and block was considered a random variable. Hepatic mineral concentrations were analyzed as repeated measures. The model included the fixed effects of treatment, day, and their interaction. Day was included as the repeated variable. Autoregressive- 1 was the covariance structure used [19]. An $\alpha$ of $\leq 0.05$ determined significance, and an $\alpha$ of 0.06 to 0.10 was considered a tendency.

\section{Results and Discussion}

\subsection{Micronutrient Intake}

Daily per head tub disappearance (mean \pm s.d.) is depicted in Figure 1. A common issue with free-choice mineral supplementation is over- or under-consumption of the freechoice mineral $[4,20]$. The stress tub label indicated that cattle should consume between 0.15 and $0.23 \mathrm{~kg} / \mathrm{d}$. Average daily disappearance from the tubs was $0.14 \pm 0.07 \mathrm{~kg} / \mathrm{d}$ or approximately $93 \%$ of the lower recommended voluntary dose. [4] demonstrated greater voluntary intake of a low-moisture, molasses-based block under pasture-based conditions, and [5] indicated intakes (approximately $0.1 \mathrm{~kg} / \mathrm{hd}$ daily) more closely matched to the cattle in the present study under dry-lot feeding conditions. Differential voluntary intakes of a low-moisture, molasses-based block under pasture and dry-lot conditions could be due to differences in basal diet palatability and digestibility. Due to a period of depressed voluntary intake of the stress tub (Figure 1; d 12 to 19), all tubs were cleaned on 19 to remove a layer of dust that had accumulated on the exposed ingestion surface of the low-moisture, molasses-based block. It is recommended to constantly monitor the ingestion surface of the low-moisture, molasses-based block for contaminants that might deter voluntary intake. Voluntary intake increased markedly following cleaning and prior to being removed from all pens on $\mathrm{d} 21$ of the 42-d study. Total micronutrient intake is 
presented in Table 3. During the initial 21-d period, steers from Tub consumed increased $(p \leq 0.01)$ amounts of $\mathrm{Co}(258.8 \%), \mathrm{Cu}(61.5 \%), \mathrm{Mn}(69.0 \%)$, and $\mathrm{Zn}(70.9 \%)$ compared with steers in Con. From d 22 to 42 , no differences $(p \geq 0.88)$ were noted between treatments for micronutrient intake. From initial to d 42, steers from Tub consumed increased $(p \leq 0.01)$ amounts of $\mathrm{Co}(133.3 \%), \mathrm{Cu}(22.8 \%), \mathrm{Mn}(28.3 \%)$, and $\mathrm{Zn}(25.3 \%)$ compared with steers from Con. Enhancement in daily mineral intake is not surprising given the fact that cattle consumed the fortified molasses block [4].

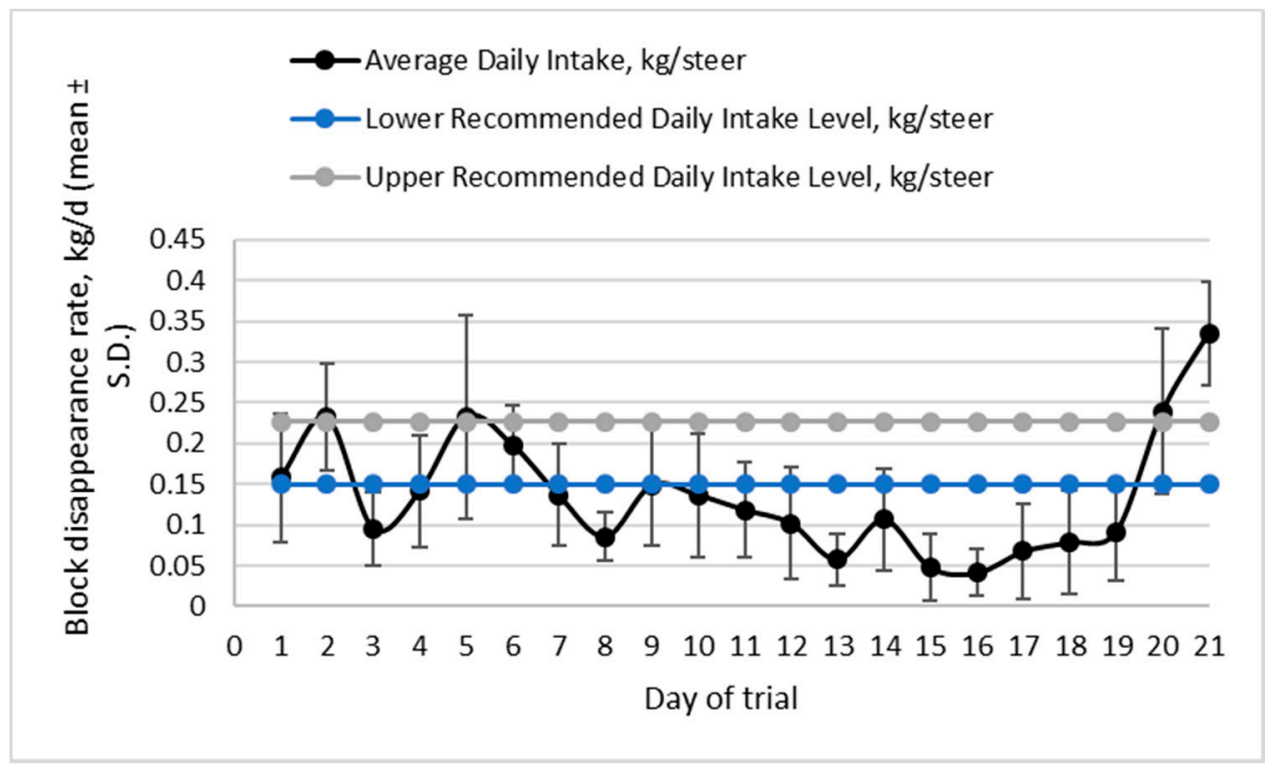

Figure 1. Daily ( $n=4$ pens; mean \pm s.d.) consumption $\left(\mathrm{kg} / \mathrm{steer}^{\mathrm{d}} \mathrm{d}^{-1}\right)$ of the cooked molasses stress tub (Stress Tub; Purina Animal Nutrition, St. Louis, MO, USA) during the 21-d period it was offered to newly weaned steer calves.

Table 3. Total mineral intake of $\mathrm{Co}, \mathrm{Cu}, \mathrm{Mn}$, and $\mathrm{Zn}$.

\begin{tabular}{|c|c|c|c|c|}
\hline \multicolumn{5}{|c|}{ Treatment $^{1}$} \\
\hline Item & Control & Stress Tub & SEM & $p$-Value \\
\hline \multicolumn{5}{|l|}{$\mathrm{d} 1$ to 21} \\
\hline $\mathrm{Co}, \mathrm{mg} /$ steer $\mathrm{d}^{-1}$ & 3.4 & 12.2 & 1.61 & 0.01 \\
\hline $\mathrm{Cu}, \mathrm{mg} /$ steer $\mathrm{d}^{-1}$ & 194.0 & 313.4 & 25.87 & 0.01 \\
\hline $\mathrm{Mn}, \mathrm{mg} /$ steer $\cdot \mathrm{d}^{-1}$ & 286.1 & 483.6 & 28.17 & 0.01 \\
\hline $\mathrm{Zn}, \mathrm{mg} /$ steer $\cdot \mathrm{d}^{-1}$ & 475.2 & 812.0 & 71.24 & 0.01 \\
\hline \multicolumn{5}{|l|}{ d 22 to 42} \\
\hline Co, mg/steer $\cdot \mathrm{d}^{-1}$ & 3.2 & 3.2 & 0.08 & 0.88 \\
\hline $\mathrm{Cu}, \mathrm{mg} /$ steer $\cdot \mathrm{d}^{-1}$ & 336.3 & 337.7 & 8.92 & 0.88 \\
\hline $\mathrm{Mn}, \mathrm{mg} /$ steer $\cdot \mathrm{d}^{-1}$ & 418.8 & 420.6 & 11.11 & 0.88 \\
\hline $\mathrm{Zn}, \mathrm{mg} /$ steer $\cdot \mathrm{d}^{-1}$ & 869.3 & 873.0 & 23.07 & 0.88 \\
\hline \multicolumn{5}{|l|}{ d 1 to 42} \\
\hline $\mathrm{Co}, \mathrm{mg} / \mathrm{steer} \cdot \mathrm{d}^{-1}$ & 3.3 & 7.7 & 0.80 & 0.01 \\
\hline $\mathrm{Cu}, \mathrm{mg} /$ steer $\cdot \mathrm{d}^{-1}$ & 265.1 & 325.6 & 13.61 & 0.01 \\
\hline $\mathrm{Mn}, \mathrm{mg} /$ steer $\cdot \mathrm{d}^{-1}$ & 352.5 & 452.1 & 15.27 & 0.01 \\
\hline $\mathrm{Zn}, \mathrm{mg} /$ steer $\cdot \mathrm{d}^{-1}$ & 672.3 & 842.5 & 39.80 & 0.01 \\
\hline
\end{tabular}

${ }^{1}$ No cooked molasses stress tub (Control) or cooked molasses stress tub (Stress Tub; Purina Animal Nutrition, St. Louis, MO, USA). 


\subsection{Liver Mineral Content}

Hepatic mineral content (DM basis) is presented in Table 4. Delivery method, dose, and type of trace mineral can influence hepatic trace mineral responses [4,21]. Hepatic mineral stores are typically increased following pulse and long-term trace mineral supplementation $[4,20,21]$. Hepatic tissue is a primary storage site for various trace minerals including $\mathrm{Cu}$ and can be analyzed to determine toxicities and deficiencies [12]. Treatment $\times$ day interactions were noted for $\mathrm{Co}(p=0.09), \mathrm{Cu}(p=0.01)$, and $\mathrm{Zn}(p=0.01)$. Hepatic concentrations of Mn were not appreciably influenced by treatment $(p=0.99)$, but hepatic concentrations of Mn differed due to day $(p=0.02)$. On d 7, steers from Tub had greater $(p \leq 0.01)$ hepatic $\mathrm{Co}, \mathrm{Cu}$, and $\mathrm{Zn}$ compared with Con. On d 21, steers from Tub had greater $(p \leq 0.01) \mathrm{Co}$ and $\mathrm{Cu}$ in hepatic tissue, and hepatic $\mathrm{Zn}$ did not differ $(p=0.83)$ on $\mathrm{d} 21$. On study $\mathrm{d} 42$ (21-d following stress tub removal), steers from Tub had greater $(p=0.01)$ hepatic $\mathrm{Cu}$; however, hepatic values for $\mathrm{Co}$ or $\mathrm{Zn}$ did not differ $(p \geq 0.34)$ between treatments. Although stress tub calves had greater mineral intake from d 1 to 21 , control calves were still consuming minerals above [22] recommendations. Hepatic Cu content was severely low initially (d 7) for both treatments groups. Analyzed dietary Mo was $0.70 \%$ (DM basis), which is nearly $65 \%$ less than the dietary Mo level that can influence Cu status in beef cattle [22]. Analyzed dietary S was $0.20 \%$ (DM basis) and was approximately $30 \%$ greater than [22] recommendations for growing and finishing beef cattle and 20\% less than the dietary $\mathrm{S}$ level that can influence $\mathrm{Cu}$ status of beef cattle [22]. Hence, decreased hepatic $\mathrm{Cu}$ might be due to elevated dietary $\mathrm{S}$, the stress of weaning, or if the $\mathrm{Cu}$ requirement of the peri-weaned beef animal is not fully understood. In the present study, the stress tub was intended to supply additional trace minerals to compensate for low feed intake during the initial 21-d feedlot receiving period. Differential response might have been observed had no trace minerals been supplemented in the basal diet (i.e., the stress tub was the only source of additional $\mathrm{Co}, \mathrm{Cu}, \mathrm{Mn}$, and $\mathrm{Zn}$ ). In the present study, use of a low-moisture, cooked molasses block was an effective means to enhance trace mineral status of calves as indicated by others $[4,5]$.

Table 4. Hepatic mineral concentrations (DM basis) on d 7, 21, or 42.

\begin{tabular}{crrrr}
\hline & \multicolumn{2}{c}{ Treatment $\mathbf{1 , 2}^{\mathbf{2}}$} & & \\
Item & Control & Stress Tub & SEM & -Value $^{\mathbf{3}}$ \\
\hline $\mathrm{d} 7$ & & & & \\
$\mathrm{Co}, \mu \mathrm{g} / \mathrm{g}$ & 0.18 & 0.43 & 0.023 & 0.01 \\
$\mathrm{Cu}, \mu \mathrm{g} / \mathrm{g}$ & 6.09 & 25.35 & 3.723 & 0.01 \\
$\mathrm{Mn}, \mu \mathrm{g} / \mathrm{g}$ & 9.05 & 9.56 & 0.785 & 0.55 \\
$\mathrm{Zn}, \mu \mathrm{g} / \mathrm{g}$ & 156.14 & 198.86 & 12.774 & 0.01 \\
\hline $\mathrm{d} 21$ & & & & \\
$\mathrm{Co}, \mu \mathrm{g} / \mathrm{g}$ & 0.13 & 0.45 & 0.037 & 0.01 \\
$\mathrm{Cu}, \mu \mathrm{g} / \mathrm{g}$ & 10.95 & 71.82 & 11.462 & 0.01 \\
$\mathrm{Mn}, \mu \mathrm{g} / \mathrm{g}$ & 7.17 & 7.80 & 0.285 & 0.09 \\
$\mathrm{Zn}, \mu \mathrm{g} / \mathrm{g}$ & 116.43 & 112.78 & 16.139 & 0.83 \\
\hline $\mathrm{d} 42$ & & & & \\
$\mathrm{Co}, \mu \mathrm{g} / \mathrm{g}$ & 0.59 & 0.21 & 0.365 & 0.36 \\
$\mathrm{Cu}, \mu \mathrm{g} / \mathrm{g}$ & 39.67 & 99.80 & 9.343 & 0.01 \\
$\mathrm{Mn}, \mu \mathrm{g} / \mathrm{g}$ & 9.21 & 95.72 & 1.145 & 0.34 \\
$\mathrm{Zn}, \mu \mathrm{g} / \mathrm{g}$ & 98.52 & 9.797 & 0.78 \\
\hline
\end{tabular}

${ }^{1}$ No cooked molasses stress tub (Control) or cooked molasses stress tub (Stress Tub; Purina Animal Nutrition, St. Louis, MO, USA). ${ }^{2}$ Treatment $\times$ day interaction: $\mathrm{Cu}(p=0.01), \mathrm{Co}(p=0.09), \mathrm{Mn}(p=0.28)$, and $\mathrm{Zn}(p=0.01)$.

${ }^{3}$ Probability value for pairwise comparison of treatments within day. 


\subsection{Growth Performance Responses}

Growth performance and observed dietary NE are presented in Table 5. Initial BW differed $(p=0.04)$ between treatments and thus was used as a covariate for all growth performance analyses. On study d 21, a tendency $(p \leq 0.08)$ was detected for BW to be $1.25 \%$ greater and ADG to be $22.8 \%$ greater for Tub compared with Con. Dry matter intake (basal diet only) did not differ ( $p=0.51$ ) during the initial $21 \mathrm{~d}$ of the experiment; however, gain efficiency was enhanced ( $p=0.03$ ) by $25.0 \%$ in steers from Tub compared with Con. These responses are similar to what has been demonstrated by others when a fortified, low-moisture molasses block was supplemented to newly weaned calves [4]. Similar dry matter intakes between treatments could be a result of management during the initial $14 \mathrm{~d}$ when intakes were programmed to promote cattle acceptance of the ration and avoid both under-and over-consumption. No differences $(p \geq 0.30)$ were detected between treatments for d $42 \mathrm{BW}, \mathrm{ADG}, \mathrm{DMI}$, or G:F for the period from d 22 to 42 . Cumulative growth performance (ADG, DMI, and G:F) was not affected by treatment $(p \geq 0.18)$. Additionally, the observed dietary NE and the ratio of observed-to-expected dietary NE did not differ $(p \geq 0.14)$ between treatments during the course of the 42 -d experiment and were in close agreement with expectations based upon formulation. Given that observed dietary NE of the control steers closely matched tabular NE, it is not surprising that differences in growth performance between treatments were not appreciable.

Table 5. Animal performance responses during the $42-\mathrm{d}$ receiving period ${ }^{\mathrm{a}}$.

\begin{tabular}{|c|c|c|c|c|}
\hline \multicolumn{5}{|c|}{ Treatment $^{1}$} \\
\hline Item & Control & Stress Tub & SEM & $p$-Value \\
\hline $\begin{array}{c}\text { Initial } \mathrm{BW}^{2}, \mathrm{~kg} \\
\text { Initial to } \mathrm{d} 21\end{array}$ & 238 & 241 & 1.0 & 0.04 \\
\hline $\mathrm{d} 21 \mathrm{BW}^{3}, \mathrm{~kg}$ & 253 & 256 & 1.1 & 0.08 \\
\hline $\mathrm{ADG}, \mathrm{kg}$ & 0.62 & 0.76 & 0.054 & 0.08 \\
\hline DMI, kg & 4.85 & 4.76 & 0.134 & 0.51 \\
\hline $\begin{array}{c}\mathrm{G}: \mathrm{F}^{4} \\
\text { d } 22 \text { to } 42\end{array}$ & 0.128 & 0.160 & 0.0080 & 0.03 \\
\hline $\mathrm{d} 42 \mathrm{BW}^{3}, \mathrm{~kg}$ & 284 & 286 & 1.8 & 0.30 \\
\hline $\mathrm{ADG}, \mathrm{kg}$ & 1.50 & 1.47 & 0.089 & 0.74 \\
\hline DMI, kg & 6.35 & 6.37 & 0.175 & 0.90 \\
\hline $\mathrm{G}: \mathrm{F}$ & 0.237 & 0.231 & 0.0132 & 0.70 \\
\hline \multicolumn{5}{|l|}{ Initial to d $422^{2,3}$} \\
\hline $\mathrm{ADG}, \mathrm{kg}$ & 1.06 & 1.11 & 0.043 & 0.30 \\
\hline DMI, kg & 5.62 & 5.56 & 0.127 & 0.68 \\
\hline $\mathrm{G}: \mathrm{F}$ & 0.190 & 0.201 & 0.0064 & 0.18 \\
\hline \multicolumn{5}{|c|}{ Dietary $\mathrm{NE}^{5}, \mathrm{Mcal} / \mathrm{kg}$} \\
\hline Maintenance & 1.76 & 1.82 & 0.037 & 0.14 \\
\hline Gain & 1.13 & 1.19 & 0.032 & 0.14 \\
\hline \multicolumn{5}{|c|}{ Observed-to-expected NE ${ }^{6}$} \\
\hline Maintenance & 1.01 & 1.05 & 0.021 & 0.14 \\
\hline Gain & 1.02 & 1.07 & 0.029 & 0.14 \\
\hline
\end{tabular}

a Initial BW was used as a covariate for all analyses. ${ }^{1}$ No cooked molasses stress tub (Control) or cooked molasses stress tub (Stress Tub; Purina Animal Nutrition, St. Louis, MO, USA). ${ }^{2}$ No shrink was applied to initial BW

${ }^{3} 4 \%$ shrink applied to $\mathrm{d} 21$ and $\mathrm{d} 42 \mathrm{BW}$ to account for digestive tract fill. ${ }^{4} \mathrm{G}: \mathrm{F}=\mathrm{ADG}, \mathrm{kg}$ divided by DMI, $\mathrm{kg}$. ${ }^{5}$ Calculated using initial unshrunk BW and d $42 \mathrm{BW}$ shrunk $4 \%$. Mature final BW was assumed to be $625 \mathrm{~kg}$ (Smith, 2020). ${ }^{6}$ Actual dietary NEm was $1.74 \mathrm{Mcal} / \mathrm{kg}$ and NEg was $1.11 \mathrm{Mcal} / \mathrm{kg}$.

\section{Conclusions}

It is concluded that the use of stress tubs containing organic trace minerals and a Saccharomyces cerevisiae fermentation product does not enhance the cumulative ADG, DMI, G:F or NE value of the diet. Stress tub application increased hepatic mineral stores during the initial 21-d receiving period and enhanced the $\mathrm{Cu}$ status of newly weaned beef steer 
calves throughout the entirety of the 42-d receiving phase experiment. Future studies should investigate whether improvements in feed efficiency during the initial 21-d period were due to enhanced mineral status from greater consumption of the mineral source, the trace mineral source, or the Saccharomyces cerevisiae fermentation product.

Author Contributions: Conceptualization, W.C.R. and Z.K.S.; Methodology, T.G.H., W.C.R., C.L.W., J.A.W. and Z.K.S.; Formal analysis, T.G.H. and Z.K.S.; Writing—original draft preparation, T.G.H.; Writing-review and editing, W.C.R., C.L.W., J.A.W. and Z.K.S.; Project administration, Z.K.S.; Funding acquisition, Z.K.S. All authors have read and agreed to the published version of the manuscript.

Funding: This research was sponsored in part by the National Institute of Food and Agriculture, the South Dakota State University Experiment Station (HATCH- SD00H690-19), and the Beef Nutrition Program at South Dakota State University.

Institutional Review Board Statement: The animal care and handling procedures used in this study were approved by the South Dakota State University Institutional Animal Care and Use Committee (Approval Number: 2002-004E).

Data Availability Statement: All data are held by Z.K.S. and can be made available upon request.

Acknowledgments: The authors wish to acknowledge the staff at the Ruminant Nutrition Center for the daily care and management of the steers used in this experiment.

Conflicts of Interest: The authors declare no conflict of interest.

\section{References}

1. Loerch, S.; Fluharty, F. Physiological changes and digestive capabilities of newly received feedlot cattle. J. Anim. Sci. 1999, 77, 1113-1119. [CrossRef] [PubMed]

2. Ott, G.C.; Freeman, S.R.; Poore, M.H.; Pickworth, C.L. 11 Impact of weaning strategy on calf performance, behavior, and activity. J. Anim. Sci. 2019, 97, 12-13. [CrossRef]

3. Galyean, M.L.; Perino, L.J.; Duff, G.C. Interaction of cattle health/immunity and nutrition. J. Anim. Sci. 1999, 77, 1120-1134. [CrossRef] [PubMed]

4. $\quad$ Ranches, J.; De Oliveira, R.A.; Vedovatto, M.; Palmer, E.A.; Moriel, P.; Silva, L.D.; Zylberlicht, G.; Drouillard, J.S.; Arthington, J.D. Low moisture, cooked molasses blocks: A limited intake method for supplementing trace minerals to pre-weaned calves. Anim. Feed Sci. Technol. 2021, 273, 114793. [CrossRef]

5. Moriel, P.; Artioli, L.F.A.; Piccolo, M.B.; Miranda, M.; Ranches, J.; Ferreira, V.S.M.; Antunes, L.Q.; Bega, A.M.; Miranda, V.F.B.; Vieira, J.F.R.L.; et al. Effects of low-moisture, sugarcane molasses-based block supplementation on growth, physiological parameters, and liver trace mineral status of growing beef heifers fed low-quality, warm-season forage. In Translational Animal Science; Oxford University Press Inc.: Cary, NC, USA, 2019; Volume 3, pp. 523-531.

6. Smith, Z.K.; Karges, K.; Aguilar, A. Evaluation of an active live yeast (Levucell Saccharomyces cerevisiae, CNCM 1-1077) on receiving and backgrounding period growth performance and efficiency of dietary net energy utilization in low health risk beef steers. Transl. Anim. Sci. 2020, 4, txaa127. [CrossRef] [PubMed]

7. Theurer, M.; Fox, J.; Aguilar, A.; Nielsen, H.; Simpson, J.; Lawrence, T. Effect of live yeast (Saccharomyces cerevisiae boulardii CNCM I-1079) feed additive on health and growth parameters of high-risk heifers in a commercial feedlot. Bov. Pract. 2019, 53, 117-127. [CrossRef]

8. Zinn, R.A.; Alvarez, E.G.; Rodriguez, S.; Salinas, J. Influence of yeast culture on health, performance and digestive function of feedlot steers. Proc. West. Sec. Amer. Soc. Anim. Sci. 1999, 50, 335-338.

9. Poppy, G.D.; Rabiee, A.R.; Lean, I.J.; Sanchez, W.K.; Dorton, K.L.; Morley, P.S. A meta-analysis of the effects of feeding yeast culture produced by anaerobic fermentation of Saccharomyces cerevisiae on milk production of lactating dairy cows. J. Dairy Sci. 2012, 95, 6027-6041. [CrossRef] [PubMed]

10. Preston, R.L. 2016 Feed Composition Table. BEEF Magazine. Available online: https://www.beefmagazine.com/sites/ beefmagazine.com/files/2016-feedcomposition-tables-beef-magazine.pdf (accessed on 1 February 2019).

11. Engle, T.E.; Spears, J.W. Effects of dietary copper concentration and source on performance and copper status of growing and finishing steers. J. Anim. Sci. 2000, 78, 2446-2451. [CrossRef] [PubMed]

12. Wahlen, R.; Evans, L.; Turner, J.; Hearn, R. The use of collision/reaction cell ICP-MS for the determination of elements in blood and serum samples. Spectroscopy 2005, 20, 84-89.

13. Smith, Z.K. Nose Color of Charolais British Crossbred Beef Steers Alters Body Weight at a Common Degree of Fatness and Marbling Score in Steers Reared Under Similar Management from Birth through Finishing. Am. J. Anim. Vet. Sci. 2020, 15. [CrossRef]

14. NRC. Nutrient Requirements of Beef Cattle, 6th ed.; National Academy Press: Washington, DC, USA, 1996. 
15. Lofgreen, G.P.; Garrett, W.N. A System for Expressing Net Energy Requirements and Feed Values for Growing and Finishing Beef Cattle. J. Anim. Sci. 1968, 27, 793-806. [CrossRef]

16. Owens, F.N.; Hicks, R.B. Can net energy values be determined from animal performance measurements? A review of factors affecting application of the California Net Energy System. Transl. Anim. Sci. 2019, 3, 929-944. [CrossRef] [PubMed]

17. Zinn, R.A.; Barreras, A.; Owens, F.N.; Plascencia, A. Performance by feedlot steers and heifers: Daily gain, mature body weight, dry matter intake, and dietary energetics. J. Anim. Sci. 2008, 86, 2680-2689. [CrossRef] [PubMed]

18. Zinn, R.A.; Shen, Y. An evaluation of ruminally degradable intake protein and metabolizable amino acid requirements of feedlot calves. J. Anim. Sci. 1998, 76, 1280-1289. [CrossRef] [PubMed]

19. Littell, R.C.; Henry, P.R.; Ammerman, C.B. Statistical analysis of repeated measures data using SAS procedures. J. Anim. Sci. 1998, 76, 1216-1231. [CrossRef] [PubMed]

20. Arthington, J.D.; Pate, F.M.; Spears, J.W. Effect of copper source and level on performance and copper status of cattle consuming molasses-based supplements. J. Anim. Sci. 2003, 81, 1357-1362. [CrossRef] [PubMed]

21. Jackson, T.D.; Carmichael, R.N.; Deters, E.L.; Messersmith, E.M.; VanValin, K.R.; Loy, D.D.; Hansen, S.L. Comparison of multiple single-use, pulse-dose trace mineral products provided as injectable, oral drench, oral paste, or bolus on circulating and liver trace mineral concentrations of beef steers. Appl. Anim. Sci. 2020, 36, 26-35. [CrossRef]

22. NASEM. Nutrient Requirements of Beef Cattle, 8th ed.; The National Academies Press: Washington, DC, USA, 2016. [CrossRef] 